\title{
EM BUSCA DE ASSOCIAÇÕES PERDIDAS? NOTAS SOBRE HÍBRIDOS, SIMETRIA E ROMANTISMO NAS POLÍTICAS DE SALVAGUARDA DE BENS CULTURAIS IMATERIAIS NO BRASIL.
}

\author{
Kelly Silva e Victor Freire'
}

\section{RESUMO}

Este artigo discute narrativas de caracterização de bens culturais imateriais produzidas e irradiadas pelo Instituto do Patrimônio Histórico e Artístico Nacional (IPHAN). Inspirados pela teoria do ator-rede, argumentamos que o objeto das políticas de registro e salvaguarda de bens imateriais são híbridos constituídos por associações heterogêneas de humanos e não-humanos. $A$ justaposição entre diferentes domínios de ação e a agência de atores ontologicamente distintos na conformação dos bens culturais imateriais registrados como patrimônio nacional é positivada nas narrativas que os descrevem. Tais fenômenos, bem como a apreensão dos bens imateriais como produto de trajetórias históricas singulares e indicadores de tradições que sustentam identidades coletivas, são interpretados como índices de certo romantismo. Somente quando renomeado como tradição, produzido a partir de correlações complexas, o legado colonial figura como actuante na configuração dos bens reconhecidos e passa a ser assim objeto de salvaguarda. No limite, estas políticas elas se voltam à salvaguarda de formas de ação e interação sobre o mundo pré-modernas.

\section{PALAVRAS-CHAVE:}

patrimônio imaterial, híbridos, fato social total, romantismo, tradição

\begin{abstract}
This article discusses narratives of characterization of intangible cultural goods produced and irradiated by the National Historical and Artistic Heritage Institute (IPHAN). Inspired by actor-network theory, we argue that the object of the policies of registration and safeguarding of immaterial goods are hybrids made up of heterogeneous associations of humans and nonhumans. The juxtaposition between different domains of action and the agency of ontologically distinct actors in the conformation of intangible cultural assets registered as national patrimony is positivated in the narratives that describe them. Such phenomena, as well as the apprehension of immaterial goods as the product of singular historical trajectories and indicators of traditions that sustain collective identities, are interpreted as indices of a certain romanticism. Only when renamed as tradition, produced from complex correlations, does the colonial legacy figure as an actuator in the configuration of the recognized goods and is thus the object of safeguarding. In the limit, these policies are aimed at safeguarding pre-modern forms of action and interaction on the world.
\end{abstract}

\section{KEYWORDS:}

immaterial heritage, hybrids, total social fact, romanticism, tradition

\footnotetext{
I Kelly Silva é professora associada do Departamento de Antropologia da Universidade de Brasília e pesquisadora produtividade em pesquisa do CNPq. Victor Freire é aluno de graduação do curso de Ciências Sociais da UnB. Este artigo é produto dos projetos de pesquisa "O governo da e pela kultura" e "Processos de invenção, transposição e subversão da modernidade: uma antropologia da cultura como categoria de governo" financiados pelo CNPq mediante os processos 457845/20147 e 401879/20II-9, respectivamente, e de bolsa de iniciação científica usufruída por Victor Freire. Os autores agradecem Sara S Morais, Rodrigo M. Ramassote e Renata Nogueira pela leitura crítica de versões anteriores deste artigo. E-mail dos autores: kellysa67@gmail.com ; vrfI507@gmail.com.
} 
Este artigo discute narrativas de caracterização de bens culturais imateriais produzidas e irradiadas pelo Instituto do Patrimônio Histórico e Artístico Nacional (IPHAN) do Brasil para legitimar o registro e salvaguarda dos mesmos. Os discursos de dossiês publicados pelo IPHAN para divulgar os bens culturais imateriais por ele reconhecidos são analisados a fim de se identificar dimensões das racionalidades e moralidades que legitimam tais políticas. A forte incidência da categoria fato social total ou de abordagens por ela inspiradas nestes documentos é tomada como um índice de uma marca importante das políticas de salvaguarda de bens imateriais: no limite elas se voltam à salvaguarda de formas de ação e interação sobre o mundo pré-modernas, ainda não-purificadas (Latour, 1994) pelo projeto classificatório contemporâneo². Além disso, a caracterização dos fenômenos patrimonializados traz à luz a ação de agentes humanos e não-humanos na conformação dos mesmos. Isso nos leva a propor que os bens culturais imateriais são híbridos. A justaposição entre diferentes domínios de ação e a agência de atores ontologicamente heterogêneos na conformação dos bens culturais imateriais registrados como patrimônio nacional é positivada nas narrativas que os descrevem. Tais fenômenos, bem como a apreensão dos bens imateriais como produto de trajetórias históricas singulares e indicadores de tradições que sustentam identidades coletivas, são interpretados como índices de certo romantismo ${ }^{3}$. Somente quando renomeado como tradição, produzido a partir de correlações complexas, o legado colonial figura como actuante na configuração dos bens reconhecidos e passa a ser assim objeto de salvaguarda.

$\mathrm{Na}$ construção da análise proposta, inspiramo-nos, sobretudo, na teoria do ator-rede proposta por Bruno Latour (2005), a qual está fortemente ancorada nos legados analíticos de Law (1986) Callon (1986), Callon et al. (200I) Cronon (199I), entre outros. Tal perspectiva opõe-se à sociologia canônica ao sugerir que a vida social não pode ser explicada exclusivamente a partir das interações e associações entre atores humanos. Há de se considerar a ação de não-humanos na produção do mundo vivido e partilhado entre os homens, e entre eles e outras espécies. Ademais, propõe-se que a ação de não-humanos seja considerada de modo simétrico à ação dos humanos. Argumenta-se que o mundo vivido seja pensado como produto de associações entre espécies heterogêneas que atuam em redes. Tal fato deve ter como implicação a dissolução do pressuposto de que a sociedade existe. Ao contrário, o objeto de investigação da sociologia deve ser os modos pelos quais isso a que o senso-comum chama de sociedade é produzida a partir de múltiplas associações. Nesta perspectiva, o que o cientista social tem diante de si como objeto de análise são coletivos constituídos por agentes de diversas ontologias, em associações.

Nos limites deste artigo, tomamos romantismo como um significante flutuante que evoca disposições coletivas e institucionais que valorizam singularidade, subjetivismo, não-determinismo; a ideia de natureza como um agente e um modelo e a perspectiva segundo a qual a realização das potencialidades

2 Bruno Latour (1994) entende por purificação os processos de separação e imposição de fronteiras ontológicas e limites de poder exclusivos entre o que são tomados como experiências, seres e domínios diversos que compõem a vida social. Por meio desses processos de separação se inscreve tais agências a certos lugares típicos-ideais para sua existência ou se projetam sobre elas configurações tidas como legítimas. Destacam-se, neste contexto, que os processos de purificação são instrumentos político pelos quais se produzem múltiplos efeitos de poder. Oposições como natureza e cultura, tradicional e moderno, política e conhecimento, justiça e poder, humanos e não-humanos, civilizados e não-civilizados são exemplares deste processo de separação.

3 Nos limites deste artigo, entendemos por identidade um certo senso de self coletivo. 
humanas se manifesta na configuração de particularismos de impossível predição. Romantismo também engloba, em nossa perspectiva, os fenômenos de projeção e transferência que caracterizaram sua manifestação na literatura e o historicismo e o organicismo que informam o modo como as categorias povo, comunidade, humanidade, cultura e por que não, identidade, são manejadas em sua vertente política (Dumont, 1994). De algum modo, parece-nos que esses diversos significados se fazem presentes nas narrativas que caracterizam os bens culturais imateriais, envoltos, ademais, em uma perspectiva nostálgica.

As narrativas de registro de bens imateriais são por nós discutidas desde uma perspectiva etnográfica. Esforçamo-nos para apreender as categorias centrais em torno das quais elas estão organizadas e daí extrair implicações analíticas. Tal perspectiva metodológica nos obriga também a ter mente os contextos em que tais narrativas de salvaguarda, enquanto tecnologias de governo (Silva, 2012), têm sido concebidas e são aplicadas e o fato de que são produto de uma série de mediações, das quais destacam-se, entre outras: a resolução IPHAN 0I/2006, que regulamenta os processos administrativos para registro de bens culturais imateriais, o Inventário Nacional de Referências Culturais (INRC) e seu manual de aplicação, os esforços de mútuo esclarecimento e tradução que marcam o diálogo entre as populações detentoras dos bens imateriais patrimonializáveis e as equipes multidisciplinares que constroem os inventários que balizam as políticas patrimoniais, a composição do conselho consultivo do IPHAN, etc.

Por um lado, reconhecemos os limites dessas políticas enquanto uma reinterpretação da vida cultural de certas coletividades (indígenas, no caso) "em termos das ideias daqueles que os saquearam" como bem ressalta Coelho de Souza $(2010,15 \mathrm{I})$. De outro, parece-nos muito importante destacar o perfil promissor das mesmas, que desafiam o sistema classificatório hegemônico ocidental. No extremo, as narrativas por nós discutidas são tecnologias de tradução que, por sua própria natureza, colaboram para expandir as formas pelas quais certos fenômenos são apreendidos. No entanto, para se fazer compreendidas para as audiências a que se destinam e legitimar as ações que propõem, alicerçam-se em ansiedades epistemológicas dos coletivos responsáveis pela sua formulação, no caso, o sistema classificatório moderno hegemônico. Daí decorre, parece-nos, a centralidade que a noção de identidade ocupa como mobilizador político para legitimar as práticas de registro e salvaguarda. Nesse sentido, é possível que a vinculação de um bem imaterial a identidades locais e regionais seja mais produto da racionalidade do Estado e daqueles responsáveis pela concepção e gestão das políticas patrimoniais, que das formas de dar sentido à relação com os bens culturais imateriais por parte das populações que os detém. De todo modo, a insistência na vinculação do bem a políticas identitárias é por nós interpretada como manifestação do romantismo que, ao menos parcialmente, informa tais políticas.

Para fins de demonstração dos argumentos propostos, três dossiês publicados pelo IPHAN são tomados como fontes primordiais de nossa análise: o saber, Modo Artesanal de Fazer Queijo de Minas, nas Regiões do Serro e das Serras da Canastra e do Salitre; o lugar, Feira de Caruaru e a celebração, Festa do Divino Espírito Santo de Pirenópolis. Esses três dossiês foram produzidos a partir da aplicação da metodologia Inventário Nacional de Referências Culturais (INRC).

Os dossiês são documentos editados e publicados pelo IPHAN com o 
objetivo de promover o registro e visibilização, em escala nacional e global eles estão disponíveis online - dos fenômenos reconhecidos enquanto bens culturais de natureza imaterial do patrimônio nacional brasileiro, assim como das ações propostas para sua salvaguarda ${ }^{4}$. Os bens culturais imateriais descritos nos dossiês são antes registrados como patrimônios culturais nacionais em um dos quatro livros possíveis:

I - Livro de Registro dos Saberes, onde serão inscritos conhecimentos e modos de fazer enraizados no cotidiano das comunidades; II - Livro de Registro das Celebrações, onde serão inscritos rituais e festas que marcam a vivência coletiva do trabalho, da religiosidade, do entretenimento e de outras práticas da vida social; III - Livro de Registro das Formas de Expressão, onde serão inscritas manifestações literárias, musicais, plásticas, cênicas e lúdicas; IV - Livro de Registro dos Lugares, onde serão inscritos mercados, feiras, santuários, praças e demais espaços onde se concentram e reproduzem práticas culturais coletivas. (Brasil, 2000)

Cada dossiê descreve de maneira propositalmente exaustiva, e a partir de múltiplas disciplinas, as referências culturais imateriais patrimonializadas (IPHAN, 2000). A publicação dos dossiês é realizada após o bem ser reconhecido enquanto patrimônio nacional pelo Conselho Consultivo do Patrimônio Imaterial, fato que é antecedido pelas práticas de identificação e inventário do bem, desencadeadas por demanda da comunidade cultural (Arantes 2009) a que o bem "pertence", por instituições da sociedade civil, ou por instituições do Estado, como o Ministério da Cultura e entidades a ele associadas, e secretarias de estado municipais ou do Distrito Federal ${ }^{5}$. Idealmente, a publicação do dossiê deve ser seguida das ações de salvaguarda nele propostas.

A descrição densa provida pelo dossiê é elaborada de modo a destacar todos os fenômenos e agentes que atuam na configuração do fenômeno patrimonializável, tal como concebido pelo coletivo que produz e administra o bem - denominado comunidade cultural - e pelas categorias de conhecimento operantes no IPHAN. Essa totalidade cultural patrimonializável é elaborada a partir de esforços de entendimento e mútua tradução entre saberes técnicos

4 Os dossiês publicados pelo IPHAN estão disponíveis no seguinte endereço eletrônico: http://portal. iphan.gov.br/publicacoes/lista?categoria=22\&busca\&pagina $=$ I

5 Arantes (2009) qualifica "comunidade cultural" como o grupo focal, criador e recriador da referência cultural passível de patrimonialização.

6 O processo de patrimonialização de um bem imaterial, processo também conhecido como registro (ou reconhecimento) de patrimônio imaterial, acontece em três etapas: identificação, registro e salvaguarda. O processo ocorre da seguinte maneira: primeiro, a proposta de registro de um bem imaterial é enviada ao Iphan para ser analisada e, assim, decide-se pela pertinência ou não da proposta. Caso haja pertinência, a proposta segue para a Instrução de Processo de Registro, momento em que se procede a seu registro, aplicando-se ou não o INRC a fim de se inventariar exaustivamente o bem. Após a identificação, a proposta segue para o registro. Para tanto, convida-se um membro do conselho consultivo do IPHAN para elaborar uma nota técnica sobre o processo de identificação. A proposta segue então para reunião do Conselho Consultivo, junto coma nota técnica, que decide se o bem será ou não registrado. Em caso positivo, o Departamento de Salvaguarda assume as práticas de governança estatal do bem. Ações de apoio e fomento constituem as práticas de salvaguarda, as quais podem incorrer inclusive em novos processos de identificação a fim de expandir o conhecimento sobre o bem. Por fim, é importante lembrar que todo o processo de patrimonialização de bem imaterial (identificação, reconhecimento ou registro e ação de apoio e fomento) é considerada salvaguarda. 
Em busca de associações perdidas? Notas sobre híbridos, simetria e romantismo nas políticas de salvaguarda de bens culturais imateriais no Brasil.

próprios do Estado e aqueles da "comunidade cultural” em questão 7.

Os dossiês promovem a materialização, em palavras e imagens, dos bens imateriais neles descritos. "Materializar o intangível, transformar memória em história" (IPHAN, 2006b) é o objetivo atribuído ao dossiê que descreve a Feira de Caruaru, por exemplo. Parece-nos que esses documentos estimulam a objetificação destes bens na medida em que promovem sua existência fora das redes sociotécnicas que lhes dão existência local, ao mesmo tempo em que os inscrevem em escalas de existência que lhes eram relativamente estranhas: a nacional e a transnacional. No espaço deste artigo, objetificação diz somente respeito ao modo como certos fenômenos são produzidos enquanto objetos, nada tendo a ver com sua acepção de crítica moral veiculada em diferentes espaços de ação social contemporâneos.

A publicação dos dossiês é uma prática de governo do IPHAN que, ao disseminar informação, trabalha já para a salvaguarda do bem reconhecido, embora as ações de salvaguarda extrapolem em muito a publicação dos dossiês. Nesse contexto, é importante destacar que o objeto das ações de salvaguarda não são os bens imateriais reconhecidos como patrimônio, em si, mas sim as "as relações que os permitem existir". Voltaremos a esta questão nas próximas seções.

Antes de seguir, é importante explicitar os limites das análises aqui empreendidas. Hoje existem mais de quarenta bens imateriais registrados como patrimônio imaterial brasileiro e boa parte deles possui dossiês publicados, física e/ou virtualmente. Priorizamos a leitura atenta de três dossiês de diferentes livros de registro. Não temos nenhuma pretensão em generalizar os argumentos demonstrados a partir da leitura dos três dossiês eleitos; pretendemos apenas pensar criticamente a partir deles, a fim de trazer à luz fatos neles implicados que não têm sido objeto de muita discussão na abordagem sobre o registro de bens culturais no Brasil.

O texto segue estruturado em duas partes, compostas por subitens, além da conclusão. Na primeira, intitulada bens imateriais como associações heterogêneas, discutimos a incidência da categoria fato social total e o reconhecimento da agência simétrica de atores humanos e não-humanos na caracterização dos bens culturais imateriais ${ }^{8}$. Na segunda seção, denominada romantismos, apontamos a centralidade de noções tais como história, tradições e identidade a estruturar os discursos sobre os bens imateriais, e o tom nostálgico que as abraça. Nos comentários finais procuramos associar o romantismo às associações heterogêneas indicadas.

\section{Bens culturais imateriais como associações heterogêneas}

O objeto das políticas de registro e salvaguarda dos bens culturais imateriais são as relações e interações que permitem a produção e reprodução dos memos. Em decorrência disso, as descrições dos bens intangíveis caracterizam os complexos de mediações que atuam na configuração do bem, desvelando a agência de humanos e não-humanos em sua composição e sua interdependência

7 Para uma análise dos desafios que se impõem nestas práticas de tradução ver : Cunha e Niemeyer (2016)

8 A categoria fato social total foi originalmente cunhada por Marcel Mauss (2009) para qualificar compreensivamente fenômenos cuja natureza não era exclusivamente nem econômica, nem política, nem religiosa, ao mesmo tempo em que eram constituídos por todas essas esferas e tinham efeito sobre todas elas. 
para com o que o senso comum tem denominado meio-ambiente e os processos históricos de que são produto. $O$ bem imaterial é assim apresentado como produto de múltiplas mediações, das quais participam, a depender do bem cultural em tela, entidades espirituais como o espírito santo, microorganismos como bactérias, e a própria história de expansão colonial. Abaixo discutimos características da poética narrativa presente nos dossiês, indicando como os mesmos revelam associações atípicas ao sistema classificatório moderno hegemônico.

Bens culturais como fatos sociais totais

(...) Os fatos que estudamos são fatos sociais totais (...) , eles põe em ação (...) a totalidade da sociedade e de suas instituições (...) Todos esses fenômenos são ao mesmo tempo jurídicos, econômicos, religiosos e mesmo estéticos, morfológicos”(Mauss, 2009: 309)

O recurso à categoria fato social total, originalmente formulada por Marcel Mauss (2009[1902-3]), é bastante recorrente nos dossiês. Sua mobilização é realizada a fim de propor um alargamento na forma de perceber os bens culturais imateriais, de modo a visibilizar como eles atravessam domínios de sociabilidade que a ideologia moderna pensa enquanto autônomos tendo, ao mesmo tempo, efeito sobre todos eles. À título de exemplo, vejamos como o dossiê Festa do Divino Espírito Santo introduz esta celebração ao leitor:

A Festa do Divino Espírito Santo de Pirenópolis é uma das maiores manifestações de devoção ao Divino do Brasil. Dialogando sem cessar com o passado e o presente, ela envolve permanentemente toda uma cidade, determinando os padrões de sociabilidade local.A cidade faz a festa e a festa faz a cidade.Através dela se marca o tempo, se reproduzem estruturas sociais e se conformam identidades coletivas e individuais. (IPHAN, 2009: 4).

(...)

A festa apresenta todos os pressupostos que nos permitem entende-la como um 'fato social total': um sistema de produção e circulação de bens e de dádivas baseados na reciprocidade, interferindo em todas as dimensões da vida social (MAUSS, 1974)." (IPHAN, 2009: 12)

(...)

"A festa organiza a sociabilidade local - antes e depois da festa já que o ciclo de preparação dos festejos e dos próprios festejos jamais se interrompe; ou seja, ciclos de 'dormência' e de 'efervescência' da festa sucedem-se indefinidamente, gerando as noções de tempo e outras representações da sociedade local. Como já afirmado, a cidade faz a festa e a festa faz a cidade. Trata-se, nas palavras de Marcel Mauss, de um 'fato social total'. (MAUSS, 1974)" (IPHAN, 2009: I I5).

A Feira de Caruaru, por sua vez, é descrita como uma composição de feiras que, juntas, conformam o que se denomina Feira de Caruaru, quais sejam, Feiras dos Importados (ou do Paraguai), Feira do Artesanato, Feira da Sulanca, Feira do Gado e Feira Livre.Alerta-se ao fato de que a Feira Livre se subdivide 
Em busca de associações perdidas? Notas sobre híbridos, simetria e romantismo nas políticas de salvaguarda de bens culturais imateriais no Brasil.

em outras 10 feiras: Feira das Frutas e Verduras; Feira de Raízes e Ervas Medicinais; Feira do TrocaTroca; Feira de Flores e Plantas ornamentais; Feira do Couro; Feira Permanente de Confecções Populares; Feira dos Bolos; Feira de Artigos de Cama, Mesa e Banho; Feira das Ferragens; Feira do Fumo (IPHAN, 2006a). O dossiê caracteriza cada uma destas feiras, mas insiste que é somente a totalidade delas que dá particularidade à Feira de Caruaru. Ressalta-se, no registro, que é a relação de tudo o que há na cidade com a Feira que deve ser objeto de registro, de modo que a apreensão adequada do que é a Feira e de seus efeitos locais é alcançada por meio da noção de fato social total.Vejamos:

\begin{abstract}
Não são os patrimônios vivos: artesãos, raizeiros e médicos populares; não é a conjunção da medicina popular com a religião; não são as Localidades em que se dividiu o espaço a ser inventariado: o Alto do Moura e o Perímetro Urbano, mas sim a relação de todos eles e de tudo isso com a Feira, que deve ser objeto de registro: seja a permanência de elementos de nossa cultura tradicional, que o tempo não apagou; seja a continuidade expressa em muitas ocasiões, em conservar a memória viva de práticas socioeconômicas e culturais que fazem parte de nossa formação como povo e como sociedade; sejam as redes de sociabilidade ensejadas por estas práticas, vivenciadas na Feira e a partir da Feira" (IPHAN, 2006a: 67 e 68).
\end{abstract}

No que diz respeito ao registro do modo artesanal de fazer queijo mineiro, a epígrafe que introduz o texto principal do dossiê evoca as várias dimensões envolvidas nesse saber, as quais se relacionam com fenômenos de ordem estética, a padrões de sociabilidade, a rotinas de trabalho, a hábitos de consumo 9 , etc. No desenvolvimento das narrativas que descrevem este saber sublinha-se que o queijo é produto de relações entre agentes de ontologia múltipla e domínios de ação que tendemos a pensar como independentes uns dos outros. Vejamos:

O Modo Artesanal de Fazer Queijo de Minas (...) agrega um conjunto de elementos materiais e simbólicos indissociáveis, ou seja, que só podem existir plenamente e ser entendidos em suas relações uns com os outros (...) Em Minas Gerais, e especialmente em suas regiões serranas, os queijos artesanais de leite cru são produto de um modo de fazer tradicional, com caráter eminentemente familiar. Resultam de uma economia rural associada à típica fazenda mineira. O ato de fazer queijo e os saberes que lhe são próprios é inseparável da casa, da propriedade, da queijaria com seus utensílios, das criações

Como a narrativa acima destaca, implicados no modo artesanal de fazer queijo de Minas estão vários domínios de sociabilidade, que englobam, entre outros, dinâmicas econômicas, morais, estéticas e técnicas. A reprodução desse saber é pensada, de certo modo, como dependente de um equilíbrio ótimo

9 "Por mais que se avance/na modernidade e que se/aprimorem a tecnologia e/os equipamentos, o modo/artesanal de fazer o queijo será/sempre uma forte referência/da melhor tradição mineira/Tradição secular que está no/cotidiano do trabalhador das/fazendas, aquele que adentra/os currais nas madrugadas/ frias para da ordenha extrair/o precioso líquido que outras/mãos irão transformar. Tradição que está no gestual/próprio dos queijeiros, homens/e mulheres, e nos utensílios/(...) das belíssimas cozinhas /mineiras com seu mobiliário/rústico e seu rico inventário de/cheiros e sabores. Tradição que/está no hábito da prosa sem/pressa em redor da mesa, com/o queijo no prato, circulando/entre os comensais junto/ como bule de café". Ângela Gutierrez 
de animais, da agricultura de subsistência, dos insumos da produção, da cozinha e da culinária, dos valores de compadrio, de tolerância, de vizinhança, de hospitalidade, entre muitos outros. Um modo de fazer que gera, como uma de suas características marcantes, e muito significativa, uma grande produção coletiva, realizada em pequena escala." (DPI/IPHAN, 20I4: 75)

entre todos esses fatores, alguns dos quais, inclusive, contraditórios à certa moralidade moderna, como "os valores do compadrio"|10. Além disso, a narrativa deste dossiê - e de outros - reconhece a ação de agentes não-humanos na conformação do modo artesanal de fazer queijo. Essa é a questão da nossa próxima seção.

\title{
Totalidade patrimonializável como híbridos e a ação de não-humanos
}

Os seguintes termos marcam uma das narrativas de registro dos fenômenos que compõem o modo artesanal de fazer o queijo de Minas:

\begin{abstract}
As explicações técnicas acerca da especificidade e qualidade do Queijo do Serro estão baseadas na combinação de fatores físiconaturais (relevo, clima, vegetação) que condicionam pastagens típicas e o desenvolvimento de bactérias específicas nesse microclima. Essas explicações, muitas vezes, atentam majoritariamente para questões como altitude, clima, solo (condições edáficas), umidade do ar, vegetação e alimentação das vacas (capins típicos de campos de altitude), além, é claro, da identificação do grupo de bactérias lácticas regionais, condicionadas pelos fatores acima. No entanto, o Queijo do Serro e seu modo de fazer específico são fruto da combinação de todos esses fatores com os modos de ser da gente serrana, com sua cultura e história construída ao longo de séculos, com suas necessidades de conservação do leite e subsistência econômica. A região reúne condições geomorfológicas, edáficas e microclimáticas que propiciaram o surgimento de pastagens naturais onde predominam o capim gordura (meloso) e capins típicos de campos de altitude. $O$ relevo é acidentado e os climas são tropicais, amenizados pelas altitudes. Possui uma densa rede de drenagem que converge para a bacia do rio Doce, destacando-se os rios Vermelho, Guanhães, Corrente, do Peixe e Santo Antônio.(DPI/IPHAN, 20 I4: 63).
\end{abstract}

A narrativa acima aborda simetricamente a ação de elementos humanos e não-humanos na conformação do queijo do Serro. Clima, morfologia do solo e vegetação recebem a mesma dignidade analítica atribuída aos homens - portadores de histórias e culturas próprias. A ação das bactérias na conformação dos queijos artesanais de Minas Gerais é destacada ao longo de todo o dossiê como ingrediente fundamental da feitura do queijo e ações são propostas para garantir a reprodução das mesmas diante dos riscos trazidos pela imposição de regras sanitárias específicas. Os queijos emergem, portanto, enquanto híbridos, como produtos da agência de humanos e não-humanos. Entre esses últimos, a agência das bactérias presentes no pingo, uma modalidade local de coalho que,

10 Neste contexto, entendemos compadrio como relações duradouras de amizade, pautadas por troca de favores. 
misturado ao leite, gera a matéria prima a partir da qual se faz o queijo, é realçada. Defende-se seu uso, sem o qual o modo artesanal de fazer queijo corre sério risco, em contraste às imposições colocadas pelas políticas sanitárias estaduais.

O pingo, fermento que dá as características específicas aos queijos artesanais, é composto por um grupo de bactérias lactofermentativas típicas de cada região. Ele é obtido com o soro que escorre dos queijos manufaturados durante a tarde e a noite do primeiro dia de maturação. É um acervo bacteriano próprio do leite, condicionado pelo clima, tipo de solo e pastagens de cada região, responsável pelo padrão de consistência, cor e sabor específico dos queijos. $O$ queijo artesanal de leite cru é um alimento vivo, em constante aperfeiçoamento pela reprodução desse acervo lático, dessa microflora bacteriana saudável: transforma-se constantemente no processo de maturação, aprimorando massa, sabor, coloração, consistência e componentes nutritivos, o que o converte em alimento de riqueza ímpar. Esse é um dos seus valores essenciais". (DPI/IPHAN, 20I4: 34).

A importância da interação entre homens e outros animais é também objeto de destaque na descrição da produção de artefatos vendidos na Feira de Caruaru, sejam eles alimentos ou artigos de couro. Salienta-se a "milenar ligação" entre os homens e o gado, central para a própria conformação dos territórios e repertórios culturais brasileiros:

Do boi tirou-se o couro; do couro fizeram-se calçados, gibões, chapéus, bolsas, alforjes, coletes, e outros artigos utilitários e ornamentais. Os artigos de couro, juntamente com a carne e os ossos do gado bovino, marcam a milenar ligação dos seres humanos com este animal. $\mathrm{Na}$ formação do povo brasileiro, não foi diferente: trazidos por portugueses e espanhóis desde o século XVII, o gado tomou conta do interior da colônia, favoreceu a penetração nas terras, conquistou espaços aos indígenas, numa luta inglória, muitas vezes, para os conquistadores (sic), mas que teve também seu lado não violento: as trocas culturais que se tornaram recorrentes entre brancos pobres - migrantes uns, foragidos e fugitivos da justiça outros - indígenas destribalizados, tornados peões nas fazendas, e negros fugidos, aquilombados ou não, e mestiços." (IPHAN, 2006a: 70).

Construção epistemológica similar também pode ser apreendida no registro da festa do Divino Espírito Santo de Pirenópolis, embora a agência não-humana em destaque seja outra. Vejamos.

A festa faz circular as graças do Espírito Santo, que se multiplicam movendo-se pelo campo e pela cidade, entrelaçando vizinhos e parentes, através da fartura, da oração e da comensalidade.A forma de agradecer ao Divino é a festa. E a certeza de receber suas bênçãos vem exatamente de se participar da festa trabalhando para o Divino, seja como Imperador ou cozinheiro, como folião, fogueteiro ou cavaleiro. A festa é

Na narrativa acima, o Espírito Santo é abordado como um agente social que distribui suas graças, sendo as graças e benções que dele emanam também agentes, uma vez que são elas que mobilizam as pessoas para se engajar na festa. A participação das pessoas na festa é abordada como uma contradádiva - na 
solidária: nela só se acumula para redistribuir, seja qual for o lugar que cada um ocupa dentro dos festejos. É a partir deste lugar que se realiza a densa troca simbólica entre o Divino Espírito Santo e seus devotos. A devoção ao Divino explica a festa. E a festa explica a cidade, constituindo-se na fonte principal de sua identidade." (IPHAN, 2009: I3).

forma de agradecimento - às bênçãos recebidas do Espírito Santo, as quais são distribuídas pelo próprio fato das pessoas participarem da festa. A festa é assim abordada como uma experiência de troca simbólica entre o Espírito Santo e seus devotos. Ora, trocas só podem ocorrer entre entidades que são consideradas agentes em sua plenitude (Graeber, 2016).

\title{
Romantismos
}

\section{A história como agente}

A recuperação de processos históricos singulares que atuaram na configuração do bem cultural narrado está presente nos três dossiês que tomamos como fonte para análise. Tal fato pode ser pensado como produto de múltiplas mediações: da resolução do IPHAN que regula os procedimentos que compõem o processo de registro, do manual de aplicação do INRC e do próprio INRC. De todo modo, há que se destacar que nas descrições apresentadas a história não é um contexto, mas um conjunto de correlações conformadas ao longo do tempo, atuantes no forjar dos fenômenos salvaguardados.

Embora os bens culturais imateriais cujos dossiês tomamos como base para discussão se refiram a fenômenos registrados em diferentes livros, quais sejam, saberes, lugares e celebrações, em todas os três destaca-se o papel fundante da expansão colonial no forjar dos interesses, necessidades e interações que levaram à configuração contemporânea do bem narrado. Em cada um dos três dossiês, fatos históricos diversos são encadeados como ingredientes que permitiram, em perspectiva de longa duração, a emergência e consolidação dos bens culturais em questão.

O Registro do Modo Artesanal de Fazer Queijo de Minas, nas regiões do Serro, da Serra da Canastra e Serra do Salitre / Alto Paranaíba assim caracteriza as origens deste saber:

As bases originais do modo de fazer queijo em Minas Gerais são atribuídas à tradição portuguesa da Serra da Estrela (...)" (DPI/IPHAN, 20|4: 32)

\begin{abstract}
"A história da produção e consumo do queijo artesanal em Minas Gerais está associada à chegada dos portugueses e à ocupação do território em consequência da descoberta do ouro e dos diamantes, no decorrer dos séculos 17 e 18. Conforme assinalado pelo historiador José Newton Meneses, coordenador da pesquisa de registro, a produção agropecuária em Minas já se iniciara antes da decadência da atividade mineradora (...) Em verdade, as regiões de mineração coexistiram com uma produção rural diversificada.
\end{abstract}

As origens da festa do Divino de Pirenópolis, por sua vez, são descritas nos seguintes termos. 
(...) A produção de queijo era inerente a um sistema de abastecimento alimentar com economia diversificada, onde agropecuária, mineração, artesanato e a prestação de vários serviços constituíam atividades e fontes de renda interdependentes." (DPI/IPHAN, 20I4: 27).

Uma das versões mais divulgadas sobre as origens da Festa localiza seus primórdios na passagem do século 13 para o 14, instituída pela Rainha Santa Isabel, esposa de Dom Diniz, o sexto rei de um Portugal em franco conflito com a Igreja Católica (IPHAN, 2009: I3).

(...)

Tal como outras festas e tradições populares oriundas da Península Ibérica, a Festa do Divino Espírito Santo desempenhou aqui um importante papel, na mediação entre as culturas que se confrontavam durante o período colonial e, consequentemente, na conformação dos padrões sociais locais.(IPHAN, 2009: 14).

Também a Feira de Caruaru é apresentada como produto do desenvolvimento histórico da expansão da exploração colonial portuguesa no Brasil (IPHAN, 2006a: 23-38). O forjar da Feira é narrado como concomitante ao desenvolvimento do povoado de Caruaru e aos interesses de exploração econômica que o guiavam.

\begin{abstract}
De acordo com Josué Euzébio Ferreira, Caruaru era, na época, uma fazenda de gado localizada às margens do Rio lpojuca. $O$ vale deste rio era utilizado como caminho para transportar o gado desembarcado para o Sertão, bem como o que vinha do Sertão com destino ao Litoral, para consumo e tração animal nos engenhos. A fazenda tornava-se um ponto de apoio; começaram a pernoitar na fazenda, fazer comida, etc. Com o tempo, viajantes (tangerinos, tropeiros, mascates, etc.) passaram a pedir refeições aos moradores da fazenda, como também dormitórios. Assim se iniciava o comércio na Fazenda Caruru, e o desenvolvimento da futura Feira de Caruaru. (IPHAN, 2006a: 24)
\end{abstract}

As narrativas discutidas acima indicam um uso peculiar da história e do passado. Ressaltam-se associações conjunturais entre fenômenos e agentes, das quais resultam as relações que permitiram a emergência dos bens culturais narrados. Por exemplo, o saber modo artesanal de fazer queijo foi desenvolvido em razão das necessidades e oportunidades criadas pela corrida do ouro e dos diamantes em Minas Gerais durante a colonização portuguesa. O lugar Feira de Caruaru, por sua vez, também emergiu no período colonial brasileiro, sendo produto da busca pela interiorização da administração portuguesa e busca de ganhos econômicos mediante a criação de gado. Nesses casos, como argumentamos acima, a história não é contexto, não é passiva; ela é agente. Não fossem essas associações do passado, os bens culturais imateriais não existiriam.

Parece-nos que a narração destas associações não implica o cultivo de uma nostalgia colonial, até porque as políticas de registro e salvaguarda dos bens imateriais se construíram, em parte, por oposição à sobrevalorização do patrimônio de "terra e cal", legado pelo período colonial (Rubino, 1996). Somente quando transformado em tradição, como algo do passado que faz parte do presente, é que o legado colonial figura como actante nos bens culturais imateriais. Somente quando reinscritas em práticas presentes, resignificadas por brasileiros e por eles incorporadas como parte de sua história, é que frações do passado colonial são rememoradas e vertidas em objeto de salvaguarda. 


\section{Tradição versus Modernidade. Riscos e acomodações}

A palavra tradição tem lugar cativo nos três dossiês aqui analisados. Ela é mobilizada em um total de 29 vezes no registro da festa do Divino de Pirenópolis, 39 vezes no dossiê do Modo Artesanal de Fazer Queijo Minas e 26 vezes no dossiê da Feira de Caruaru, junto com sua forma plural e sua forma adjetiva (tradicional). Sendo de uso do senso-comum, a palavra tradição, em si, é polissêmica" . Em razão disso, o IPHAN procura normalizar seu significado na resolução $001 / 2016$, onde propõe que, para fins das políticas de registro e salvaguarda de bens culturais imateriais, tradição deve ser entendida como "“dizer através do tempo', significando práticas produtivas, rituais e simbólicas que são constantemente reiteradas, transformadas e atualizadas, mantendo, para o grupo, um vínculo do presente com o seu passado." (Iphan 2006). Nesta acepção, tradição é parte do presente, da contemporaneidade. Contudo, os usos da categoria nos dossiês se dá a fim de retratar fenômenos que se opõem, em alguns contextos, ao que é apresentado como modernidade ou modernização. Vejamos.

A feira de Ferragens, que compõem a Feira de Caruaru, é retratada em seu dossiê com grande positividade em razão de nela se comercializar utensílios domésticos fabricados a partir do reaproveitamento de materiais, por oposição ao que é denominado "sociedade do descartável" e consumismo contemporâneos:

\footnotetext{
Esta criatividade presente na atividade de criação e fabrico, nesta como em outras Feiras, constitui um destaque para o registro, por conta da permanência de hábitos artesanais de reutilização de materiais já sucateados, costume que vem na contramão da sociedade do descartável, dos bens materiais constantemente renovados, exigência do consumismo contemporâneo. (IPHAN, 2006a: 6I)
}

Além disso, sublinham-se os modos como esferas de produção e circulação dos bens comercializados nesta feira se sobrepõem, por oposição à típica segregação das mesmas na organização econômica capitalista.

\footnotetext{
Um outro dado interessante para o registro, é a vizinhança entre a 'fábrica', ou a oficina de criação dos produtos, e a barraca de venda: ressurgência da antiga instituição da proximidade entre o centro produtor e o comerciante, ambos compartilhando o mesmo prédio" (IPHAN, 2006a: 62)
}

Sobre a Feira do Artesanato, que também compõem a feira de Caruaru, e onde se comercializam estátuas e panelas em barro, xilogravuras, bordados, artigos de palha, de couro e de madeira, etc., o dossiê destaca uma rara prática comercial entre artesãos e comerciantes. Artesãos (principalmente de outras cidades) distribuem suas obras para os donos de barraca, sem deixar com eles qualquer meio de contato ou documentação atestando a entrega dos produtos: os artesãos apenas deixam um número específico de obras junto aos comerciantes, dão os preços e retornam qualquer dia (muitas vezes meses depois) 
para buscar o apurado das vendas. Tal fenômeno é fortemente enaltecido no dossiê, como resquício de modos de socialidade tradicionais, que devem ser salvaguardados:

Através de ocorrências como estas, pode-se analisar a continuidade de determinadas relações sociais hoje quase desaparecidas na sociedade contemporânea, entre artesãos e feirantes.” (IPHAN, 2006a: 46 e 47).

As ideias de tradição, tradicional ou mesmo artesanal também são mobilizadas em poéticas de resistência a fenômenos que são vistos como ameaçadores da reprodução dos bens culturais em pauta. Assim, o aumento do afluxo de turistas que se deslocam a Pirenópolis para assistir sua Festa do Divino é visto como ameaça à reprodução de seu modus operandi e efeitos tradicionais. Neste contexto, o que se denomina como turismo cultural é apresentado como solução a este desafio:
(...) Para seus moradores mais tradicionais, a festa 'vem perdendo a gra- ça', deixando de ser um espaço de encontro e reconhecimento para a população local, que, antes, usufruía plenamente dos festejos, num uni- verso cultural próprio que não sofria interferências externas. $O$ 'tama- nho' que a festa vem tomando e a presença de 'forasteiros' - permanen- tes ou passageiros - 'dispersa' os referenciais tradicionais da população, até então plenamente inseridos em seus modos de viver a festa: as redes de sociabilidade local, com seus códigos próprios de usufruto e convi- vência, seus ícones e referências espaciais e culturais.
(...)
Por tudo isto se verifica que, mais que selecionar o turista capaz de apreciar a cultura popular, é necessário fomentar nas instâncias públicas locais uma atitude permanentemente comprometida com o respeito à cultura local e com a garantia dos espaços de expressão da Festa do Divino. (IPHAN, 2009: I I 8 e II9).

Dada a importância da ação de bactérias particulares e de outros microorganismos, produzidos in locu, para a produção artesanal de queijos de Minas, regras sanitárias impostas pelo Estado moderno são retratadas em seu dossiê como ameaça aos saberes tradicionais de feitura dos queijos.

\begin{abstract}
A tradição do queijo artesanal (...) sempre se fez em formas e bancas queijeiras confeccionadas com madeiras nobres da região por hábeis marceneiros. As formas de madeira deixaram de ser usadas há muitos anos, sendo substituídas por formas plásticas, de higienização mais fácil. Por imposição da legislação sanitária de 2002, as bancas de madeira têm sido substituídas por bancas de ardósia, granito ou aço inox. Cabe notar que essas inovações têm causado alterações no 'pingo' [coalho], assinaladas por produtores ouvidos na instrução do processo de registro. $O$ pingo é o fermento lácteo natural, fundamental no processo de fermentação e cura dos queijos artesanais das regiões citadas." (DPI/ IPHAN, 20I4: 32)

(...)
\end{abstract}

Procura-se salvaguardar as tradições narradas nos dossiês, por sua vez, por uma razão especial: elas são apresentadas, projetadas, como fonte de identidade das populações detentoras dos bens culturais imateriais. Embora de algum modo naturalizada pela epistemologia de nossa sociedade, uma reflexão atenta 
Foi também por iniciativa da Associação dos Amigos do Serro - Aaser que a Secretaria de Cultura do Estado de Minas Gerais apresentou ao Iphan, em agosto de 200I, o pedido de registro do queijo artesanal do Serro no Livro dos Saberes e, consequentemente, seu reconhecimento como Patrimônio Cultural do Brasil. Ambas as iniciativas tratavam de preservar o modo tradicional de fazer queijo, contrapondo-se à imposição de 'melhores' práticas, que desconsideravam completamente os conhecimentos tradicionais e os procedimentos secularmente adotados pelos produtores de queijo de leite cru da região do Serro. (DPI/IPHAN, 20|4: I6).

sobre a vinculação entre tradição/ções e identidade/s indica que esses fenômenos estão longe de ter relações necessárias (Stratherm 1988, Viveiros de Castro, 2002 Coelho Souza, 2010). O fato de serem projetados como universais revela, desde nosso olhar, perspectivas românticas nas políticas patrimoniais do IPHAN. Eis o problema da última seção deste texto.

\section{Ansiedades identitárias}

Como indicamos na introdução, as descrições que os dossiês apresentam sobre os bens culturais imateriais são produto de uma série de mediações. Dentre elas, a resolução IPHAN 0I/2006 é muito importante na medida em que regula os procedimentos para instauração de processo de demanda de registro de bens culturais imateriais. A resolução argumenta pela necessidade de registro de tais bens, entre outros, nos seguintes termos:

CONSIDERANDO que se entende por bem cultural de natureza imaterial as criações culturais de caráter dinâmico e processual, fundadas na tradição e manifestadas por indivíduos ou grupos de indivíduos como expressão de sua identidade cultural e social;

CONSIDERANDO que a instituição do Registro de Bens Culturais de Natureza Imaterial, além de contribuir para a continuidade dessas manifestações, abre novas e mais amplas possibilidades de reconhecimento da contribuição dos diversos grupos formadores da sociedade brasileira; (IPHAN, 2006. Grifos nossos)

O Estado propõe que os bens culturais imateriais cujo registro pretende-se regular são expressão da identidade cultural e social dos diversos grupos que compõe a sociedade brasileira. Figurar como sinal diacrítico para o cultivo de identidades coletivas e específicas, a um só tempo, é o que legitima, desde o ponto de vista do Estado, o reconhecimento de determinados fenômenos como patrimônio nacional ${ }^{12}$. Propomos nesta seção um estranhamento desta rede de causalidade a fim de refletirmos sobre as racionalidades e moralidades que a

I2 Tal reconhecimento permite às populações detentoras dos bens culturais registrados mobilizar recursos de natureza diversa aos quais elas não teriam acesso se não fosse mediante o reconhecimento deste bem enquanto patrimônio (Silva, 2016). Por vezes, o acesso a direitos básicos de cidadania estão condicionados pelo reconhecimento por parte do Estado de uma identidade diferenciada por grupo, assim alimentada pela vinculação com um determinado bem cultural reconhecido como patrimônio. 
informam.

O dossiê que descreve o modo artesanal de fazer queijo de Minas assim associa a fabricação do queijo e a subjetividade daqueles que se envolvem nesta atividade:

Carregadas de sentido de pertencimento e de identidade, essas práticas - fazer e comer queijo - também caracterizam os nativos de Minas Gerais para os demais brasileiros. Não por acaso, em vários lugares do Brasil, e especialmente na região Sudeste, o queijo fresco de leite cru costuma ser chamado de "Queijo Minas", (...) e se constitui em uma das maiores expressões da "mineiridade"' (DPI/IPHAN, 2014: 14).

Todos esses relatos e fontes documentais denotam a continuidade histórica da tradição dos queijos artesanais no cotidiano de produtores e consumidores mineiros, desde o século 18 e pelos séculos seguintes. A permanência dessa tradição até a atualidade e sua referência para a identidade de tantos grupos sociais de Minas Gerais são, em si mesmos, elementos significativos do valor patrimonial do Modo de Fazer Queijo de Minas." (DPI/IPHAN, 20I4: 30).

Tais narrativas propõem uma aguda correlação entre o saber modo tradicional de fazer queijo minas e a identidade coletiva mineiros. Sustenta-se que é mesmo em razão da centralidade que o fazer e o consumir o queijo tem na sociabilidade local que o mesmo deve ser reconhecido como patrimônio.

A associação da Festa do Divino Espírito Santo à identidade pirenopolitana, por sua vez, é construída no dossiê que a caracteriza da seguinte forma:

\begin{abstract}
A Festa do Divino Espírito Santo de Pirenópolis, considerada a mais relevante manifestação de devoção ao Divino do país, desempenha papel central na formação da identidade cultural local: um jeito próprio de viver e sentir o mundo onde não há um tempo 'antes' e um tempo 'depois da festa', nem distâncias intransponíveis entre o catolicismo oficial e o catolicismo popular. (IPHAN, 2009: 12).

(...)

Assim, em meio às suas ocupações tradicionais e às novidades trazidas pelo turismo, os moradores de Pirenópolis continuam se reconhecendo e refazendo sua identidade no ciclo permanente de festividades que marcam a vida social local. Deste modo, são preservados e reproduzidos permanentemente os valores rurais e religiosos dessa sociedade.(IPHAN, 2009: 20).
\end{abstract}

Salta aos olhos, nas narrativas apresentadas acima, a redução das dinâmicas de reprodução social das populações detentoras dos bens culturais imateriais à relação das mesmas com tais bens. Há um silenciamento das múltiplas posições de sujeito que os detentores dos bens ocupam em prol de uma sobrevalorização da relação com o bem, que é retratada como fonte de subjetivação e, assim, de identificação.

Além disso, os bens culturais imateriais são alçados à condição de representantes absolutos de uma determinada população, projetando-se sobre ela o compartilhamento da oposição entre real e representação. Como afirmei em outro contexto (Silva e Ferreira 2016), "a ideia de representação sugere que existe uma realidade distinta e anterior ao modo como narramos ou representamos a mesma. Ela envolve uma distinção entre o que seja modelo e o que é (ou seria) a realidade. Um dos efeitos mais profundos desse modo de apreender 
o mundo, segundo Mitchell (apud. Keane 2007, I I), seria a distinção entre corpo e alma, material e imaterial, matéria e espírito." Nos casos em tela neste artigo, os bens culturais imateriais são tomados como signos de identidades. A esse respeito, Gonçalves (2005: 32) sugere que o patrimônio existe em pelo menos duas dimensões distintas. Ele constitui algo, mas também representa

\footnotetext{
um patrimônio entendido como parte e extensão da experiência, e, portanto, do corpo, e um patrimônio entendido de modo objetificado, como coisa separada do corpo, como objetos a serem identificados, classificados, preservados, etc. Por um lado, um patrimônio inseparável do corpo e suas técnicas - o corpo, que é, em si, um instrumento e um mediador social e simbólico entre o self e o mundo (...); e, por outro lado, um patrimônio individualizado e autonomizado, com a função de assumir o papel de 'representação' ou de 'expressão' emblemática de categorias que são transformadas em alguma forma de entidade, seja a nação, o grupo étnico, a região, a natureza, entre outras.
}

Temos muitas dúvidas se tais bens seriam mobilizados como fonte de subjetivação e identificação destas populações em outros contextos. Desse modo, parece-nos importante perguntar em que medida a associação dos bens culturais a identidades coletivas, é em alguma medida, produzida pelos instrumentos de governo com os quais o Estado trabalha para o registro de tais bens, tal como o INRC ${ }^{13}$.

Essa questão em nada ameaça o valor nacional destes bens, parece-nos. O que nos intriga, antes, é a necessária vinculação dos bens a identidades grupais. Em que medida isso não é uma projeção de fantasias românticas que sustentam que as fronteiras entre comunidades políticas e o acesso a determinados direitos e status de cidadania (Mandani 1998) devem estar assentes em fronteiras culturais, em modos de ser e viver específicos? (Dumont 1994). Essa é, pois, parte central da moralidade que sustenta o Estado-nação (e que sustentou os Estados coloniais) e pode ser importante a analistas e pesquisadores observar o quanto as instituições de governo da cultura projetam este modo de imaginar as coisas sobre as populações governadas.

\section{Considerações finais}

Ao longo deste artigo procuramos identificar categorias, racionalidades e moralidades recorrentes nas narrativas de registro de bens culturais imateriais no IPHAN. Esse esforço implicou observar atentamente as narrativas pelas quais os bens culturais imateriais são caracterizados. Este exercício foi realizado por meio da análise de três dossiês: Dossiê Feira de Caruaru, Dossiê Festa do Divino Espírito Santo de Pirenópolis e Dossiê Modo Artesanal de Fazer Queijo de Minas, nas regiões do Serro, da Serra da Canastra e do Salitre.

Inspirados pela teoria ator-rede, demonstramos ao longo do texto que o objeto de registro e salvaguarda são associações heterogêneas entre agentes humanos e não-humanos. Ademais, as narrativas de registro parecem dar uma atenção simétrica a esses diferentes agentes. Assim, o objeto de salvaguarda são híbridos, são relações (associações) que permitem ao bem existir e ser repro- 
duzido. Em muitos casos, essas associações sobrepõem domínios de ação que são imaginados como autônomos na narrativa hegemônica da modernidade, tais como economia, religião, política, natureza, cultura, arte, etc. Parece-nos ser esta uma das razões a explicar o porquê da categoria fato social total ser recorrentemente mobilizada nos dossiês para descrever a produção e reprodução dos bens culturais imateriais, as quais se dão na interseção desses diversos reinos de ação. No limiar, as narrativas de registro de bens culturais imateriais promovem uma superação de associações estabilizadas como domínios ou reinos autônomos de relações, denominados "sociedade", por um lado, e "natureza", de outro (Latour, 2005).

Além disso, as associações heterogêneas descritas são nomeadas como tradicionais, em muitos casos, e em seu forjar a história colonial não é contexto; é agente. O legado colonial é renomeado como tradição e assim é denominado por ser ainda actuante na configuração dos bens reconhecidos. É somente nesta qualidade e como fato subvertido, antropofagizado por brasileiros que o passado colonial é retomado e salvaguardado.

Ao mesmo tempo, contudo, os discursos para salvaguarda projetam sobre as associações que elas desejam proteger e preservar ansiedades epistemológicas próprias do sistema classificatório moderno, da qual se destacam ansiedades identidades ancoradas em tradições que são celebradas como "contribuição dos diversos grupos formadores da sociedade brasileira;" (IPHAN, 2006).

Referências

ARANTES, Antônio. "Sobre Inventários e outros instrumentos de salvaguarda do patrimônio cultural intangível: ensaios de antropologia pública”. In Anuário Antropológico, 2007/2008. Rio de Janeiro:Tempo Brasileiro, 2009.

CALLON, M. Some elements of a sociology of translation domestication of the scallops and the fisherman of St Brieux Bay. In Power, Action and Belief. A New Sociology of Knowledge? (ed. Law, J.) Keele: Sociological Review Monograph, p. 196-229, 1986.

CALLON, M., LASCOUMES, P. and BARTHE, Y. Agir dans un monde incertain: Essai sur la démocratie technique. Paris: Le Seuil, 200 I.

COELHO DE SOUZA, Marcela. 2010.A cultura invisível. In Anuário Antropológico/2009 - I. Rio de Janeiro:Tempo Brasileiro, p. I49-174. 2010.

CRONON, W. Nature's Metropolis: Chicago and the Great West. New York: Norton, 199I.

CUNHA, Manuela Carneiro da \& CESARINO, Pedro de Niemeyer (Orgs.). Políticas Culturais e Povos Indígenas. I. Ed. São Paulo: Editora Unesp, 2016.

DPI/IPHAN. Dossiê do Modo de Fazer Queijo Artesanal de Minas. I ed. Brasília: Iphan Sede, 20I4. Disponível em: http://portal.iphan.gov.br/uploads/publicacao/ Dossie_Queijo_de_Minas_web.pdf

DUMONT, Louis. German Ideology. From France to Germany and back. Chicago, The University of Chicago Press, 1994.

FONSECA, Maria Cecília Londres. O patrimônio em processo: trajetória da 
política federal de preservação no Brasil. 2. ed. Rio de Janeiro: Editora UFRJ/ Minc-Iphan, 2005.

GRAEBER, David. Dívida. Os Primeiros 500 anos. São Paulo, Três Estrelas, 2016.

GONÇALVES, José R. S. Ressonância, materialidade e subjetividade: as culturas como patrimônios. Horiz. antropol. [online]. Porto Alegre: Editora UFRGS, vol.I I, n.23. p. I5-36. 2005.

IPHAN. Inventário nacional de referências culturais - INRC: manual de aplicação. Brasília: Instituto do Patrimônio Histórico e Artístico Nacional, 2000. Disponível em: http://portal.iphan.gov.br/uploads/ckfinder/arquivos/Manual_do_INRC.pdf IPHAN, 2006. RESOLUÇÃO $n^{\circ} 00 \mathrm{I}$, de 03 de agosto de 2006. Disponível em: http://portal.iphan.gov.br/uploads/ckfinder/arquivos/Resolucao_00I_de_3_de_ agosto_de_2006.pdf

IPHAN. Dossiê da Feira de Caruaru. IPHAN, 2006a. Disponível em: http://portal. iphan.gov.br/bcrE/pages/folBemCulturalRegistradoE.jsf

IPHAN. Dossiê da Festa do Divino Espírito Santo de Pirenópolis. IPHAN, 2009. Disponível em: http://portal.iphan.gov.br/uploads/ckfinder/arquivos/Dossie_festa_\%20do_divino_pirenopolis.pdf

KEANE, Webb. Christian Moderns. Freedom \& Fetish in the mission encounter. I ed. Berkeley: University of California Press, 2007

LATOUR, Bruno. Jamais Fomos Modernos: Ensaio de Antropologia Simétrica. Tradução: Carlos Irineu da Costa. I ${ }^{a}$ edição, Rio de Janeiro: Editora 34 - Associada à Editora Nova Fronteira, 1994.

LATOUR, Bruno. Reassembling the Social: An Introduction to Actor-Network-Theory. First Edition, Oxford: Oxford University Press, 2005.

LAW, J. On Power and Its Tactics:A View From The Sociology Of Science. In The Sociological Review. 34/l: p. I-38. 1986.

LAW, J. On the Method of Long-Distance Control:Vessels, Navigation and the Portuguese Route to India. In Power, Action and Belief. A New Sociology of Knowledge? (ed. Law, J.) Keele: Sociological Review Monograph, p. 234-263, I 986 MAMDANI, M. Ciudadano y súbdito. África contemporánea y el legado del coIonialismo tardío. Madri: Siglo XXI Editores, 1998.

MAUSS, Marcel. Ensaio sobre a dádiva. In: Mauss, Marcel. Sociologia e Antropologia. (trad. Paulo Neves) São Paulo: COSACNAIFY, 2009 [1902-3] pp. 45 - 179.

MORAIS, Sara S. Culturas inventariadas: reflexões antropológicas acerca dos processos de patrimonialização de bens imateriais no Brasil. In: XII CONLAB, 2015, Lisboa. Livro de Atas do $1^{\circ}$ Congresso da Associação Internacional de Ciências Sociais e Humanas em Língua Portuguesa. Lisboa: Leading Congressos, 20I5. v. I. p. 9446-9460, 2015.

SILVA, Kelly. Global flows of government practices: development technologies and their effects. Vibrant, Virtual Braz. Anthr. Brasília, v. 9, n. 2, p. 70-102, Dec. 2012.

SILVA, Renata. Irmandades Negras, reconhecimento e cidadania. Curitiba: Ed. Appris, 2016.

SILVA e FERREIRA. A objetificação da cultura para a construção nacional de Timor-

Leste. Perspectivas a partir de coleções de tais.Veritas - Revista Científica da Universidade Nacional Timor Lorosa'e, vol. 4, n 3, p. 43-59. 2016. 
SILVA, Kelly; SIMIAO, Daniel. Coping with "traditions": the analysis of East-Timorese nation building from the perspective of a certain anthropology made in Brazil.Vibrant,Virtual Braz. Anthr., Brasília, v. 9, n. I, p. 360-38I, June 2012 .

STRATHERN, Marilyn. The gender of the gift. Problems with women and problems with society in Melanesia. Berkeley: University of California Press, 1988.

VIVEIROS DE CASTRO, Eduardo. O mármore e a murta: Sobre a inconstância da alma selvagem. In:Viveiros de Castro, E. A inconstância da alma selvagem e outros ensaios de antropologia. São Paulo: Cosaic \& Naif, p. I8I-264, 2002. 